\title{
ETHNOBOTANICAL SURVEY ON MEDICINAL PLANTS USED IN BURKINA FASO IN THE TREATMENT OF BREAST CANCER, PHYTOCHEMISTRY AND ANTIOXIDANT ACTIVITIES: EUPHORBIA POISSONII PAX AND FLUEGGEA VIROSA (WILLD.) VOIGT. (EUPHORBIACEAE)
}

\author{
Hyacinthe Mindiempo Thiombiano ${ }^{*}$, Mindièdiba Jean Bangou ${ }^{1,2}$, \\ Aminata P. Nacoulma ${ }^{4}$, Béboila Ouoba ${ }^{1}$, Mamadou Sawadogo ${ }^{1}$, \\ Amandine Lema ${ }^{1}$, Tangbadioa Hervé Coulidiati ${ }^{3}$, \\ Hermann Yempabou Ouoba ${ }^{1,3}$, and Georges Anicet Ouedraogo ${ }^{1,2}$.
}

${ }^{1}$ University of Nazi BONI, Training and Research unit in Sciences and Technology (UFRST), Department of Biochemistry and Microbiology, University of Nazi BONI, 01 BP 1091

Bobo-Dioulasso 01, Burkina Faso. hyacinthethiombiano@gmail.com

${ }^{2}$ Laboratory for Research and Education in Animal Health and Biotechnology (LARESBA), University of Nazi BONI, 01 BP 1091 Bobo-Dioulasso 01, Burkina Faso.

${ }^{3}$ University Joseph Ki-Zerbo, Life and Earth Sciences Training and Research Unit (UFRSVT), Laboratory of Plant Biology and Ecology (LABEV), University of Nazi BONI, 03 BP 7021 Ouagadougou 03, Burkina Faso

${ }^{4}$ Department of Applied Pharmaceutical Sciences, UFR Health Sciences, Université Ouaga I Joseph Ki-Zerbo, Ouagadougou, Burkina-Faso.

Cite this article:

Thiombiano H.M., Bangou M.J., Nacoulma A.P., Ouoba B. , Sawadogo M., Lema A., Coulidiati T.H., Ouoba H.Y., Ouedraogo G.A. (2022), Ethnobotanical Survey on Medicinal Plants Used in Burkina Faso in the Treatment of Breast Cancer, Phytochemistry and Antioxidant Activities: Euphorbia poissonii Pax and Flueggea virosa (Willd.) Voigt. (Euphorbiaceae). African Journal of Biology and Medical Research 5(1), 116. DOI: 10.52589/AJBMRUDC9CHLG

\section{Manuscript History}

Received: 3 Dec 2021

Accepted: 21 Dec 2021

Published: 12 Jan 2022

Copyright $\odot 2020$ The Author(s). This is an Open Access article distributed under the terms of Creative Commons Attribution-NonCommercialNoDerivatives 4.0 International (CC BY-NC-ND 4.0), which permits anyone to share, use, reproduce and 1 redistribute in any medium, provided

1 the original author and source are credited.
ABSTRACT: This study presents an ethnobotanical survey, a quantification of polyphenols and antioxidant activities on medicinal plants used in the treatment of breast cancer in the cities of Bobo-Dioulasso and Fada N'Gourma conducted among traditional practitioners. For this purpose, after the survey analyses, Euphorbia poissonii Pax (Euphorbiaceae) and Flueggea virosa (Willd.) Voigt. (Euphorbiaceae) were chosen. A methanolic extraction with soxhlet was performed on these plants. Then, the quantification of phenolic compounds was done by spectrophotometric method with Folin Ciocalteu reagent and aluminum chloride respectively. Likewise, the antioxidant activity was evaluated by three methods (ABTS, DPPH and FRAP). A total of 103 traditional practitioners were surveyed and 47 species divided into 27 families were obtained. Among the total extracts, the leaves of Flueggea virosa gave the highest content of total phenolics (52.05 $\pm 1.49 \mathrm{mg}$ EAG/100mg extract) and the root gave the highest content of flavonoids $(3.30 \pm 0.32 \mathrm{EQ} / 100 \mathrm{mg}$ extract $)$. The best antioxidant activity was observed at the ABTS method with best results obtained for the total extracts of Flueggea virosa $(8413.78 \pm 110.16 \mu \mathrm{mol} E A A / g)$. The results of the different phytochemical and antioxidant activities could partially justify the traditional use of these plants in the management of breast cancer patients.

KEYWORDS: Cancer, Ethnobotany, Flavonoids, Polyphenols, Antioxidant. 


\section{INTRODUCTION}

Cancer remains one of the public health concerns that has been increasing for years in the world and particularly in Africa (Coulidiati et al., 2019). Cancer is not only a concern in developed countries, it is a disease that is also prevalent in developing countries (Aliam, 2017; WHO, 2018; Coulidiati et al., 2019). According to WHO, in 2018, lung, liver, stomach, colon and breast cancers cause the most deaths per year. Moreover, at the National Hospital Center of Ouagadougou (Burkina Faso), breast cancer tops the list of female genital cancers, followed by cervical cancer (Ouédraogo, 1992; Ministry of Health, 2017). In view of the invasiveness of cancers, if no action is taken by 2030, there will be 1.4 million new cases with 1.05 million deaths as forecast (Globocan, 2012). There are modern treatments such as radiotherapy, chemotherapy, surgery... which depend on the evolution of the cancer (Globocan, 2012). However, these means of treatment and anticancer products are very expensive and are not yet available in developing countries (Sano et al., 1998; Zongo et al., 2015; Coulidiati et al., 2019). Besides this, plants have always occupied an important place in human care.

Plants are of paramount importance in all civilizations that have used plants either wild or cultivated for food, defense, and clothing (Ouoba et al,. 2018). The therapeutic use of plants for the treatment of human diseases is very old (Bangou et al., 2012) and has progressed with the history of humanity (Zakkad, 2017). In Burkina Faso, traditional medicine plays a very important role in the health of the population. Medicinal plants are used by traditional healers to treat all kinds of diseases for example malaria, ulcers, diabetes and especially cancer (Bayala et al., 2014; Coulidiati et al., 2019). This form of medicine is accessible to all, unlike modern medicine, and is less expensive (Sano et al., 1998). An important element of cultural heritage, traditional medicine and pharmacopeia remain the main source of primary health care for $70 \%$ of the Burkina Faso population (Zerbo et al., 2011). Plants are well known to contain several metabolites directed against many diseases. Indeed, the Euphorbiaceae family is involved in many pharmacological activities around the world (China, Tanzania, Uganda ...). Until the beginning of the 20th century, almost all medicines were plant-based and it is estimated that two thirds of today's medicines have a natural origin (Zakkad, 2017). Today medicinal plants still remain the primary reservoir of new drugs, as they are considered as a source of essential raw materials that allows for the manufacture of new drugs through the discovery of molecules of interest (Abou-chaar et al., 1980; Belkhiri, 2018). It is therefore important to evaluate the therapeutic potential of plants used in the treatment of various diseases from a pharmacological point of view in order to evaluate them. It is within this framework that the present study was conducted.

The general objective of this study was to conduct an ethnobotanical survey among traditional practitioners, a quantification of polyphenols contents and antioxidant activity on extracts of the most listed medicinal plants used in the treatment of breast cancer in the cities of BoboDioulasso and Fada N'Gourma. 


\section{MATERIALS AND METHODS}

\section{Study sites}

Bobo-Dioulasso is located in the Hauts-Bassins region in western Burkina Faso. Its geographical coordinates are $11^{\circ} 10^{\prime} 59.999^{\prime \prime}$ North, $4^{\circ} 16^{\prime} 59.999^{\prime \prime}$ West. Bobo-Dioulasso is the economic capital of Burkina Faso. It is the second largest city in terms of population after Ouagadougou (the country's capital) covering an area of $136.78 \mathrm{~km}^{2}$ with 90,3887 inhabitants (RGPH, 2020). The climate is South Sudanese with an average rainfall of $900.8 \mathrm{~mm}$ (KöppenGeiger). The vegetation is dominated by wooded savannahs and open forests and includes all subtypes, from wooded savannah to grassy savannah (Guinko, 1984). Fada N'Gourma is located in the eastern region of Burkina Faso with coordinates of $12^{\circ} 03^{\prime} 00^{\prime \prime}$ North and $0^{\circ} 22^{\prime} 01^{\prime \prime}$ East. This city is populated with 180356 inhabitants (RGPH 2020) covering an area of $36 \mathrm{Km}^{2}$. The climate is South Sudanese with an average rainfall of $565 \mathrm{~mm}$ (Köppen-Geiger). Fada N'Gourma has vegetation characterized by a shrubby savanna (Monographie de la Région de l'Est, 2009). The population is mixed in these study areas and the local languages commonly spoken are Dioula, Fulfuldé, Gourmanchtèma, and Mooré (Figure 1).

Biological activities were conducted at the Laboratoire de Recherche et d'Enseignement en Santé et Biotechnologie Animale (LARESBA) of the Institut de Développement Rural (I.D.R).

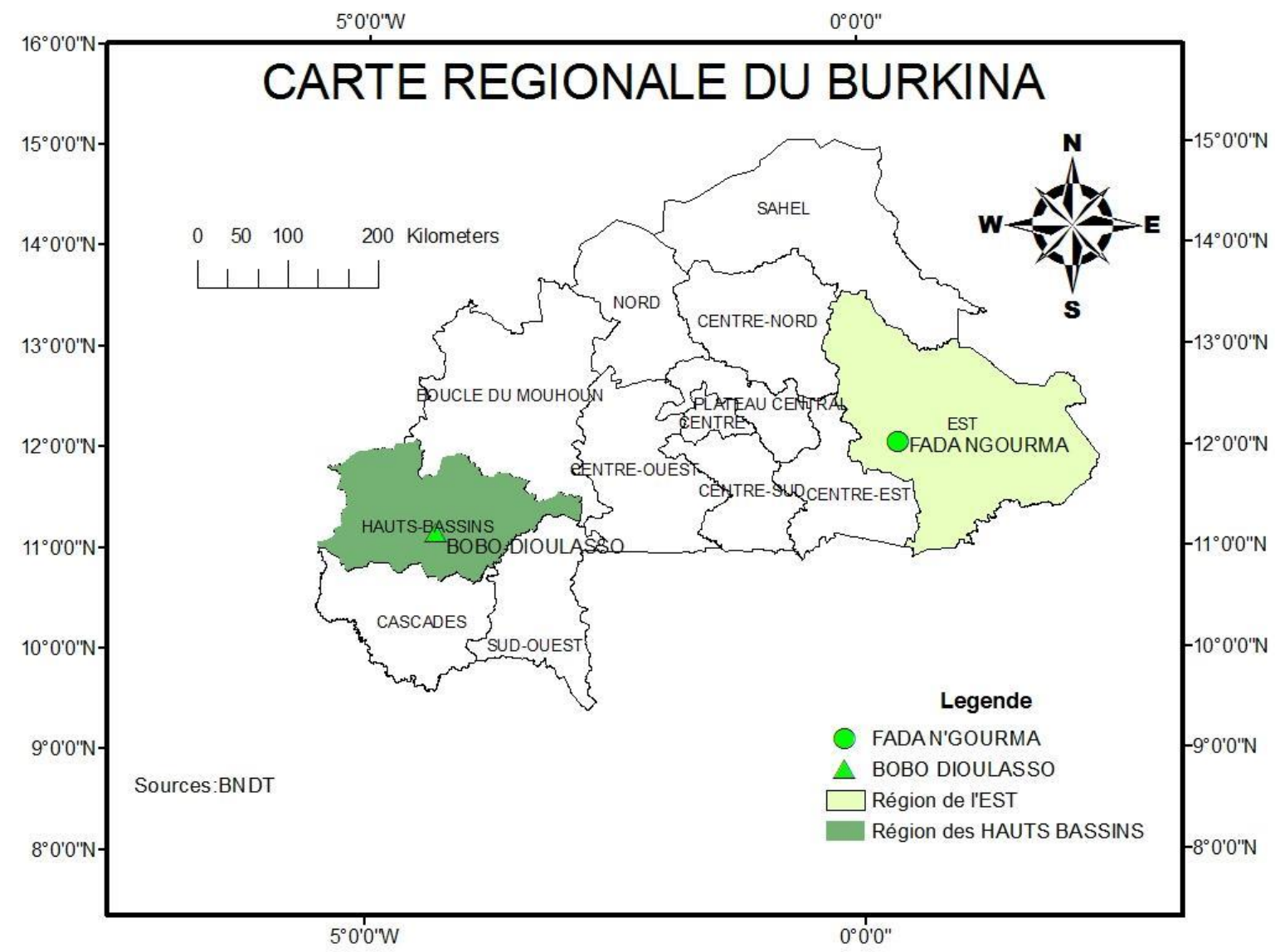

Figure 1: Ethnobotanical survey areas 


\section{Ethnobotanical survey}

It took place during the period from August to November 2020 and involved one hundred and three (103) traditional practitioners divided into two (2) groups. The methodology used was a semi-structured interview using a survey form with each traditional practitioner. The data collected was about their knowledge of breast cancer, the names of the plants they use for the treatment of breast cancer and the parts of the plant used.

\section{Plant material}

The plant material consisted of leaves, bark and roots of Euphorbia poissonii and Flueggea virosa collected in December 2020 in the classified forest of Dendérésso (Bobo-Dioulasso) and in the forest of Siétougou (Fada N'Gourma). The two species were previously identified by Dr. Yempabou Hermann OUOBA Botanist and Phytoecologist at the Nazi BONI University before the harvest. Then, the samples were dried in the laboratory under the shelter of the sun, at room temperature and pulverized with an aluminum mortar to obtain powder. The powders thus obtained were packaged and labeled in zip lock bags that were finally used for the different operations in the laboratory.

\section{Solvents and reagents}

All solvents were analytical grade. Agilent Cary $60 \mathrm{UV}-\mathrm{Vis}$ Spectrophotometer was used in all spectrophotometric measurements. Ascorbic acid, ferric chloride $\left(\mathrm{FeCl}_{3}\right)$, aluminum chloride $\left(\mathrm{AlCl}_{3}\right)$, potassium acetate, quercetin, 2,2-Diphenyl-1-picrylhydrazyl (DPPH), 2,2'azinobis (3-ethylbenzothiazoline)-6-sulfonic (ABTS), Folin-Ciocalteau reagent, gallic acid, sodium carbonate, methanol was obtained from Sigma Chemical Co. (St. Louis, MO, USA). Millipore deionized water was used throughout. Thiazolyl Blue Tetrazolium Bromide (Sigma Aldrich, USA), Dimethyl Sulfoxide (Sigma Aldrich, USA).

\section{Extraction}

$15 \mathrm{~g}$ of plant powder of each sample was loaded in cartridges, extracted with $200 \mathrm{~mL}$ using the soxhlet for at least 4 hours. After recovery of the solvent, the extract was concentrated, collected in a petri dish and dried under ambient laboratory conditions. The yields $(\mathrm{R})$ of the extractions were calculated by the following formula:

$\mathrm{R}=\frac{\text { mass of the extract }}{\text { extracted } \text { mass }} * 100$

\section{Determination of polyphenolic compounds}

Determination of total polyphenols: The estimation of total extractable phenolic compounds was performed by the Folin- Ciocalteu method described by Dakio et al. (2020). The sample solution diluted to one hundredth from the stock solution was used. We used three tubes into which a $0.125 \mathrm{~mL}$ volume of the diluted extract solution plus a $625 \mu \mathrm{L}$ volume of the $0.2 \mathrm{~N}$ Folin-Ciocalteu reagent incubated for $5 \mathrm{~min}$ was introduced. After a volume of $0.5 \mathrm{~mL}$ of a solution of sodium carbonate at $75 \mathrm{~g} / \mathrm{L}$ in distilled water is then added and the mixture incubated for two (02) hours. A fourth tube was used for the preparation of the blank which contained a volume of $125 \mu \mathrm{L}$ of distilled water plus $125 \mu \mathrm{L}$ of Folin-Ciocalteu reagent and sodium carbonate. At the end of the incubation, the optical densities are read at $760 \mathrm{~nm}$ with a spectrophotometer. The standard calibration curve was plotted using gallic acid $(0-200 \mathrm{mg} / \mathrm{L})$ 
$\left(y=0.004668 x+0.034 ; R^{2}=0.9991\right)$. A total of three $(03)$ readings are taken for each extract and the result given is an average from these analyses. The results are expressed as $\mathrm{mg}$ Gallic Acid Equivalent per $100 \mathrm{mg}$ extract or fraction (mg GAE/ $100 \mathrm{mg}$ extract).

Determination of total flavonoids: The method used for the estimation of flavonoid levels in plant extracts and fractions is that described by Dakio et al. (2020). The sample solution diluted to the hundredth was used to perform the operation. A total of four (04) tubes were prepared in which a volume of $625 \mu \mathrm{L}$ of the diluted solution of each sample was introduced, then we added to the first three (03) tubes $625 \mu \mathrm{L}$ of $\mathrm{AlCl}_{3}$. The fourth tube considered as the control received $625 \mu \mathrm{L}$ of methanol and then incubated for $10 \mathrm{mn}$ in the dark. Quercetin $(0-100 \mathrm{mg} / \mathrm{L})$ was used as a standard for the development of the calibration curve $\left(\mathrm{y}=0.01259 \mathrm{x} ; \mathrm{R}^{2}=\right.$ 0.9990). After incubation three readings are taken per extract sample using a spectrophotometer at $415 \mathrm{~nm}$ wavelength the result given is an average of the three. The results are expressed as mg Quercetin Equivalent (QE) per $100 \mathrm{mg}$ of extract (mg QE/100mg).

\section{Antioxidant Activities}

\section{Reducing power by the FRAP method}

The FRAP (Ferric Reducing Antioxidant Power) method is based on the ability of the extracts to reduce ferric ion $\left(\mathrm{Fe}^{3+}\right)$ to ferrous ion $\left(\mathrm{Fe}^{2+}\right)$. The total antioxidant capacity of each plant extract was determined by the method described by Dakio et al. (2020). The sample solution was prepared with distilled water to $0.5 \mathrm{~mL}$ of sample solution, followed by $1.25 \mathrm{~mL}$ of phosphate buffer $(0.2 \mathrm{M})$ and $1.25 \mathrm{~mL}$ of potassium hexacyanoferrate were added. This mixture was incubated for 30 minutes in a water bath at $50^{\circ} \mathrm{C}$. After that, $1.25 \mathrm{~mL}$ of trichloroacetic acid $(10 \%)$ was added and the whole centrifuged for 10 minutes at $300 \mathrm{rpm} .0 .625 \mathrm{~mL}$ of the supernatant was added to $0.625 \mathrm{~mL}$ of distilled water and $0.125 \mathrm{~mL}$ of freshly prepared iron chloride $(\mathrm{FeCl} 3)$ with distilled water $(0.1 \%)$. The absorbance of the latter mixture is read at $700 \mathrm{~nm}$ by a spectrophotometer. Ascorbic acid was used to produce the calibration curve $(\mathrm{y}=$ $\left.0.003270 x ; R^{2}=0.9990\right)$. A blank was also prepared under the same conditions with distilled water. Determination of iron (III) reducing activity was performed in triplicate and expressed as $\mu \mathrm{mol}$ of ascorbic acid equivalent (AAE)/g of extract.

\section{Anti-free radical activity by the $\mathrm{DPPH}^{\bullet}$ radical inhibition method.}

The antiradical activity of the extracts by the DPPH method, is their ability to scavenge the 2,2-diphenyl-1-picrylhydrazyl radical (DPPH ${ }^{\bullet}$ ). The method used was as described by Dakio et al. (2020). $375 \mu \mathrm{L}$ of methanolic sample solution is mixed with $750 \mu \mathrm{L}$ of DPPH solution $(20 \mathrm{mg} / \mathrm{L})$. The mixture is incubated for $15 \mathrm{~min}$ in the dark. A blank is also prepared with methanol in place of the DPPH $(20 \mathrm{mg} / \mathrm{L})$ solution. Measurements are performed by a spectrophotometer at $700 \mathrm{~nm}$. Ascorbic acid was used as the standard $(-0.02224 \mathrm{x}+0.348$; $\left.\mathrm{R}^{2}=0.9966\right)$. The average of three readings was used and the results expressed as $\mu \mathrm{mol}$ of ascorbic acid equivalent (AAE)/g of extract.

\section{Reducing power by the $\mathrm{ABTS}^{\bullet+}$ method.}

The method used is the one described by Dakio et al. (2020).The sample solution is prepared with distilled water. $990 \mu \mathrm{L}$ of ABTS $^{\bullet+}$ (2,2'-azinobis (3- ethylbenzothiazoline)-6-sulfonic) solution $(0.1 \mathrm{mg} / \mathrm{mL})$ is added to $10 \mu \mathrm{L}$ of sample solution. The blank here is ethanol. Measurements are performed by a spectrophotometer at $734 \mathrm{~nm}$. Ascorbic acid was used as 
the standard $\left(\mathrm{y}=-0.0007874 \mathrm{x}+0.709 ; \mathrm{R}^{2}=0.9993\right)$. The average of three readings was used and the results expressed as $\mu \mathrm{mol}$ of ascorbic acid equivalent (AAE)/g of extract.

The results of antioxidant activities were determined by the formula:

$$
C=\frac{c * D}{M * C i}
$$

$\mathrm{C}=$ concentration of free radical scavenging compounds in $\mu \mathrm{mol} \mathrm{AAE} / \mathrm{g}$ extract or fraction

$\mathrm{c}=$ concentration of the sample read on the standard curve

$\mathrm{D}=$ dilution factor of the sample (100)

$\mathrm{Ci}=$ initial concentration of the solution to be determined $(10 \mathrm{mg} / \mathrm{ml})$

$\mathrm{M}=$ molar mass of ascorbic acid $(176.1 \mathrm{~g} / \mathrm{mol})$

\section{Statistical analysis:}

The data analysis was done as follows: the analysis of the survey forms and the statistical analysis of the results. Thus, the responses to the questionnaires were coded, entered and processed using the EXCEL 2013 spreadsheet.

$F=\frac{\text { Number of citations for the considered plant }}{\text { Total number of citations for all plants }} * 100$

F : citation frequency

\section{RESULTS AND DISCUSSION}

\section{Data on the Plants Surveyed}

The survey data identified 47 species divided into 27 families used in traditional medicine in the fight against breast cancer (Figure 2). In Bobo-Dioulasso, 32 species were identified by 50 traditional practitioners, with the best citation rates being Flueggea virosa, Khaya senegalensis, and Ximenia americana, which were respectively $12.30 \%, 9.23 \%$ and $6.15 \%$. In the city of Fada N'Gourma, of the 18 full-time tradipractitioners, 34 species were identified, of which Euphorbia poissonii (13.20\%), Flueggea virosa (9.43\%) and Ximenia americana $(7.54 \%)$ had the highest citation rates. In the group of part-time tradipractitioners, 35 tradipractitioners were interviewed and 19 species were identified with Flueggea virosa leading the citations (16.66\%) followed by Euphorbia poissonii $(6.66 \%)$. This exploitation of data allowed us to note that there is an overlap of plant families between these two cities of study, in particular Euphorbiaceae, Combretaceae, Meliaceae, Mimosaceae, Anacardiaceae, Asclepiadaceae, Annonaceae, Caesalpiniaceae, Zygophyllaceae, Bombacaceae (figure 3). In addition, one of the plants (Flueggea virosa with a variation in citation rate from $9.43 \%$ to $16.66 \%$ ) in the study overlaps in both surveyed areas. Euphorbia poissoni is absent in the Bobo-Dioulasso area. The reason for this absence is certainly related to its habitat. Indeed, this plant develops in a particular environment, it lives in savannahs, rocky areas... (Arbonnier, 
2002; Thiombiano et al., 2012). It is true that our study plants have not yet been studied for their efficacy in the treatment of breast cancer in Burkina Faso ; Researchers have isolated some molecules from plants (Balanites aegyptiaca, Lantana ukambensis) used in the treatment of cancers (Gnoula et al., 2008; Bayala et al., 2014). According to an ethnobotanical survey, some study were been conducted in Benin on traditional knowledge between two ethnic groups, the researchers were found that E. poissonii was used extensively in the treatment of some inflammatory diseases such as cancer with an average use value of 1.465 (Gbesso et al., 2020). Also in 2010, an ethnobotanical survey was conducted in southwestern Nigeria by Ashidi and collaborators on plants used in cancer treatment. Kareru et al. in 2007 in Kenya conducted ethnobotanical surveys on Flueggea virosa and it was found that it is used in the treatment of breast cancer. Also in 2015 Magaji et al. in their studies proved that Flueggea virosa is used in multiple treatments. In addition, anti-cancer activities on KB, L1210 and P388 (Tatematsu et al., 1991) and MCF-7, MDA-MB-231 (Monkodkaew et al., 2009) cell lines were found with Flueggea virosa extracts. It appears from this study that our plants were fairly cited by the traditional healers. Also, many ethnobotanical studies have noted the usefulness of these plants in the traditional recipes of traditional practitioners. Because of these numerous uses of these plants by traditional practitioners, our interest in studying the two species could be justified.

\section{Parts of the plants used}

Various parts of the plants are used. Among traditional healers in Bobo-Dioulasso, leaves and roots were the most commonly used parts, with $34.78 \%$ and $21.73 \%$ respectively (Figure 4). As for the traditional healers in the city of Fada N'Gourma, the parts used varied from leaves (20\%); stem bark (21.53\%); roots (27.69\%); fruits (10.76\%); latex $(6.15 \%)$; flowers $(3.07 \%)$ and the whole plant $(10.76 \%)$ for the group of full-time healers (Figure 5.1). Also in the group of part-time practitioners, the parts used varied: stem bark $(39.47 \%)$, leaves $(36.84 \%)$, roots $(15.78 \%)$, the whole plant (5.26\%) and fruits (2.63\%) (Figure 5.2). As for the parts used, the leaves had a citation rate of $34.78 \%$ compared to $17.39 \%$ of the barks in Bobo-Dioulasso and in Fada N'Gourma they had a citation rate of $28.42 \%$ compared to $25.48 \%$ of the barks cited by the different groups of therapists. The parts of the plant are almost all used for the preparation of medicines. The degree of use differs from one to another. hese results are similar to those of Zerbo et al. (2011) who showed that leaves are predominantly stressed during traditional treatments. These parts are much more used because they are easier to access. Moreover, these parts constitute the storage places of secondary metabolites (NacoulaOuédraogo, 1996). 
African Journal of Biology and Medical Research ISSN: 2689-534X

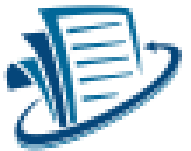

Volume 5, Issue 1, 2022 (pp. 1-16)

www.abjournals.org

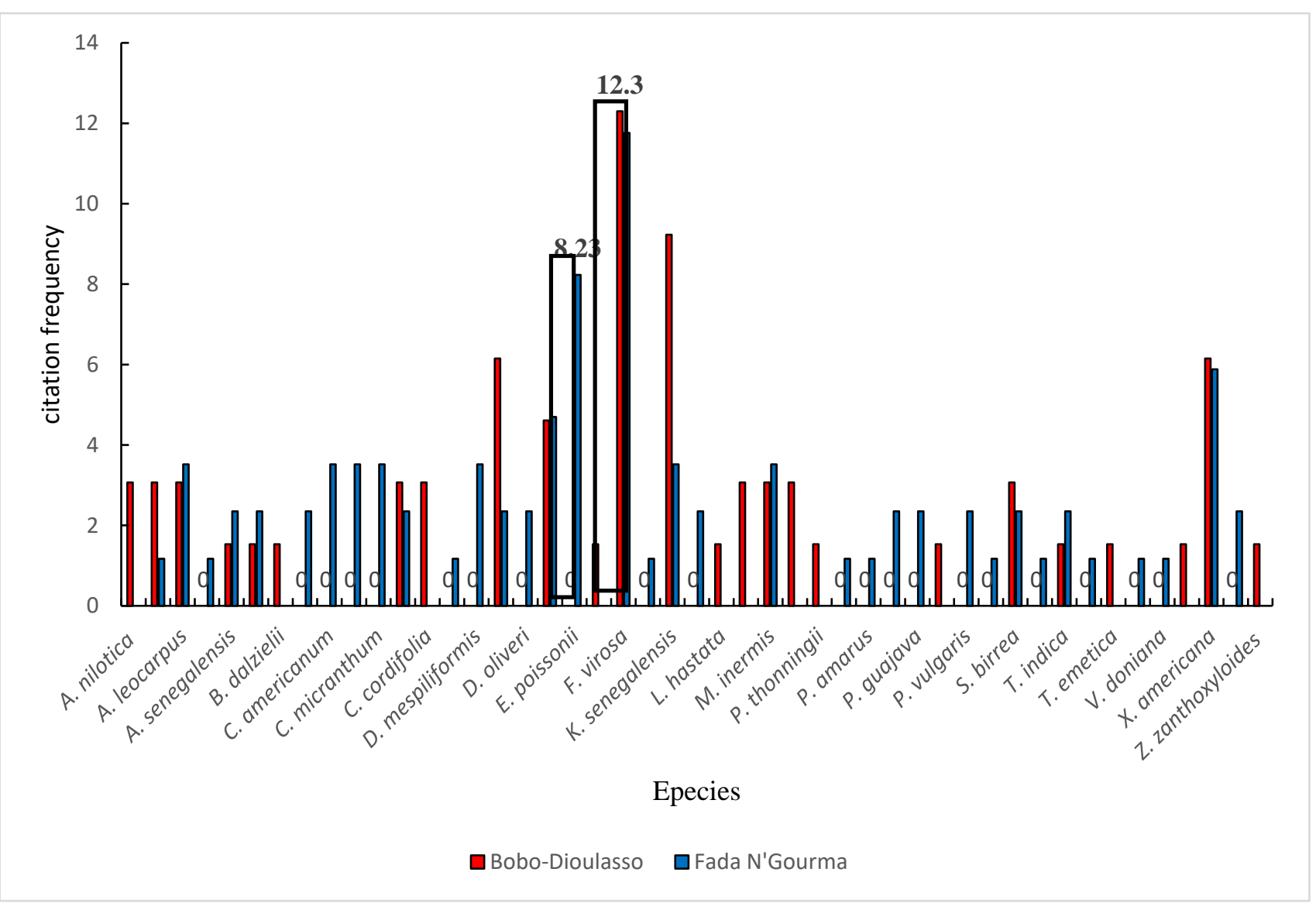

Figure 2: Frequency of citations of medicinal plants in different cities

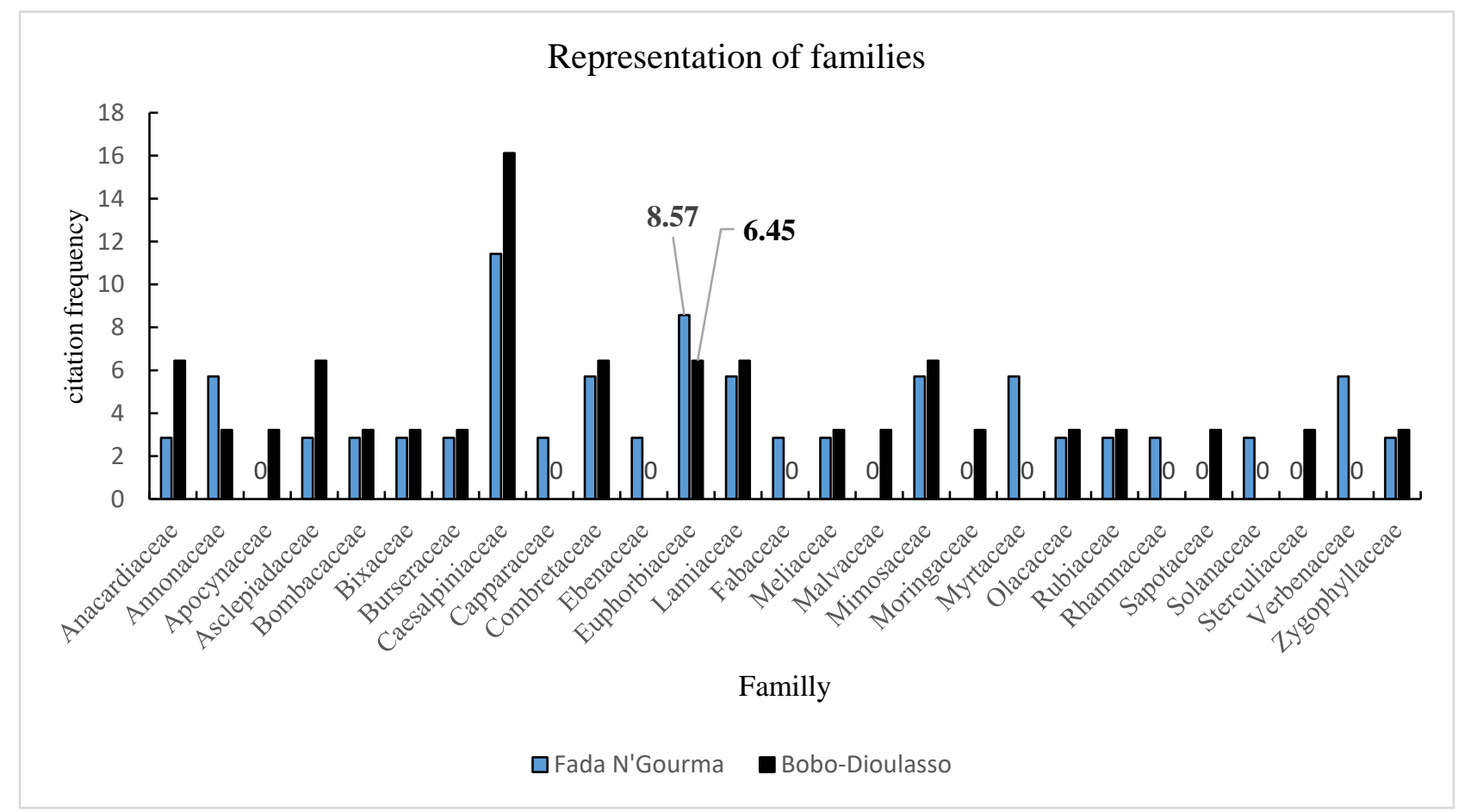

Figure 3: Families represented in the Bobo-Dioulasso and Fada N'Gourma areas 
African Journal of Biology and Medical Research

ISSN: 2689-534X

Volume 5, Issue 1, 2022 (pp. 1-16)

www.abjournals.org

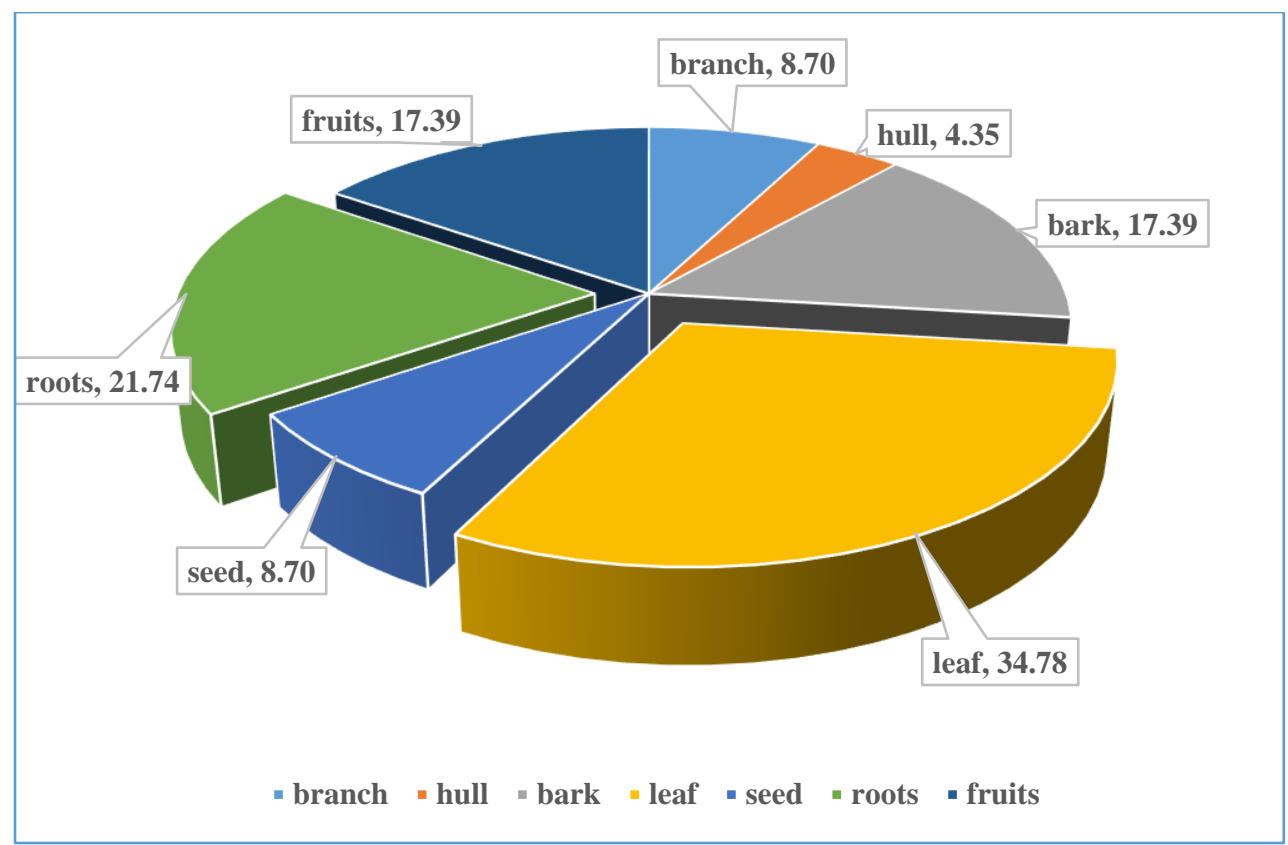

Figure 4: Frequency of citation of the parts used
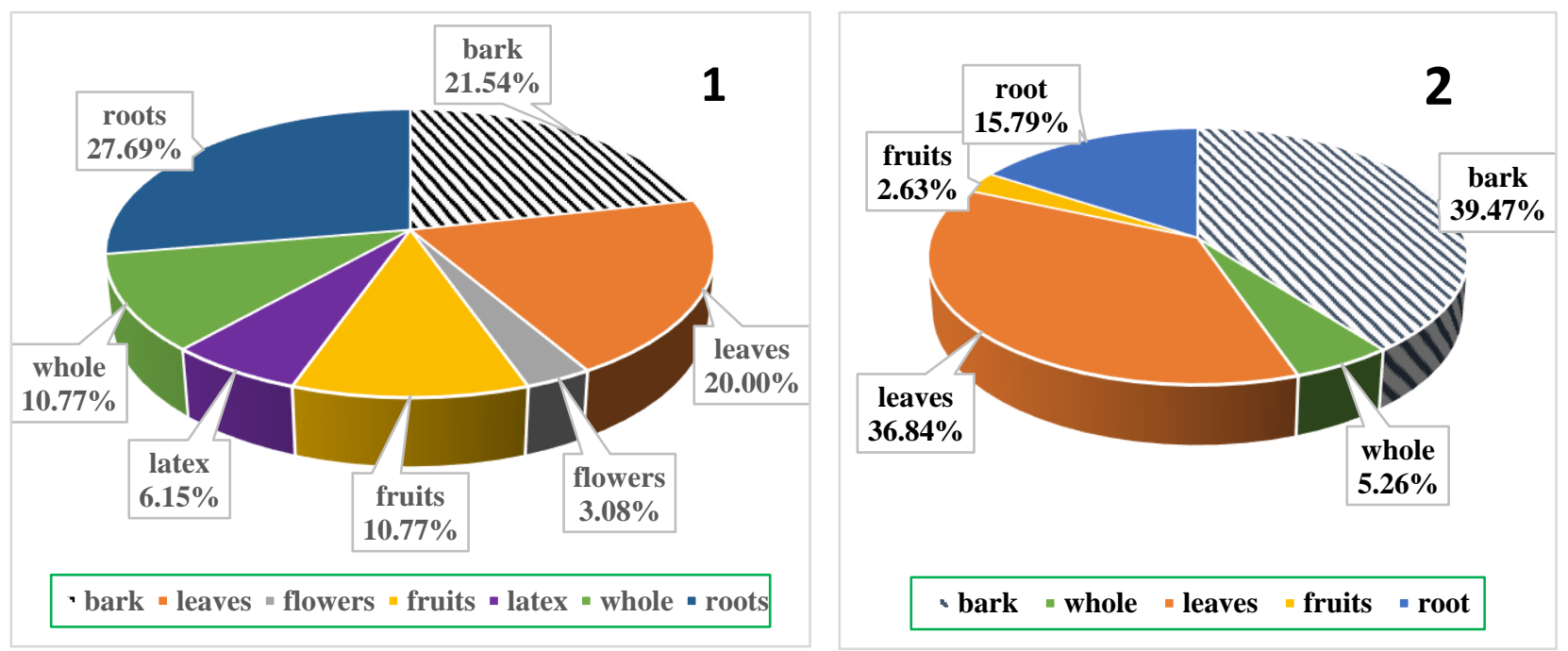

Figure 5: Frequency of citation: 1: of parts used ; 2: of parts used 
African Journal of Biology and Medical Research

ISSN: $2689-534 \mathrm{X}$

Volume 5, Issue 1, 2022 (pp. 1-16)

www.abjournals.org

\section{Mode of Preparation and Mode of Administration}

In general, the modes of preparation and administration varied among the different traditional practitioners. In Bobo-Dioulasso, three modes of preparation were listed (powder, decoction and incineration) where decoction was the most represented (50\%) (Figure 6.A). The most listed mode of administration was "drinking" with $38.70 \%$ (Figure 6.B). In Fada N'Gourma, "decoction" was more frequently cited as the mode of preparation (50\%) (Figure 7.A) in the group of full-time practitioners as well as in the group of part-time practitioners (92\%) (Figure 7.B). For the use of the treatment, the mode of administration varied between "bathing", "drinking", "bathing and drinking", "chewing" and "massage" respectively with frequencies of use of $13.63 \% ; 45.45 \% ; 18.18 \% ; 3.03 \%$ and $19.69 \%$ in the full-time group (Figure 7.C). Similarly, part-time practitioners used "bathing," "drinking," "drinking and bathing," "leaching," and "massage" respectively, with proportions of 28.94\%, 47.36\%, 18.42\%, 2.63\%, and $2.63 \%$ for self-care (Figure 7.D).
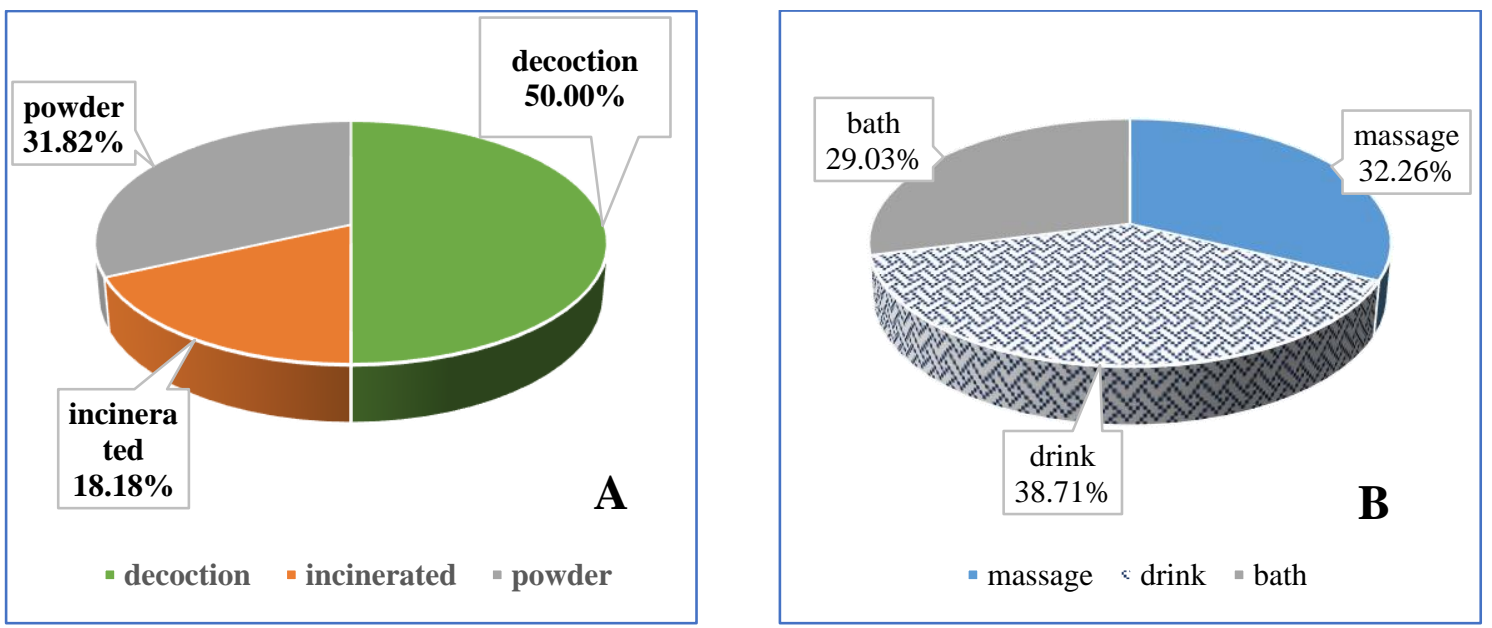

Figure 6: Frequency of Citation : A : preparation mode ; B : administration mode
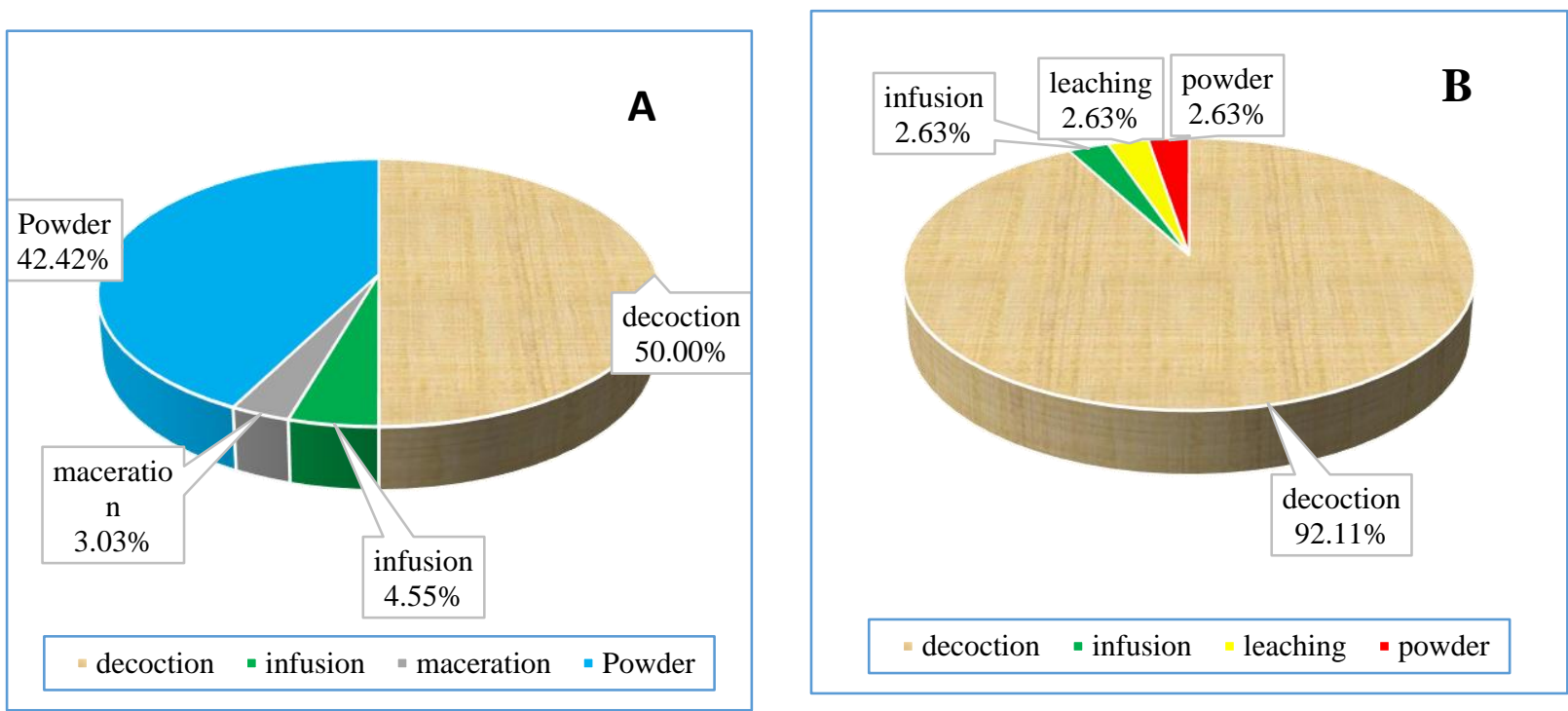

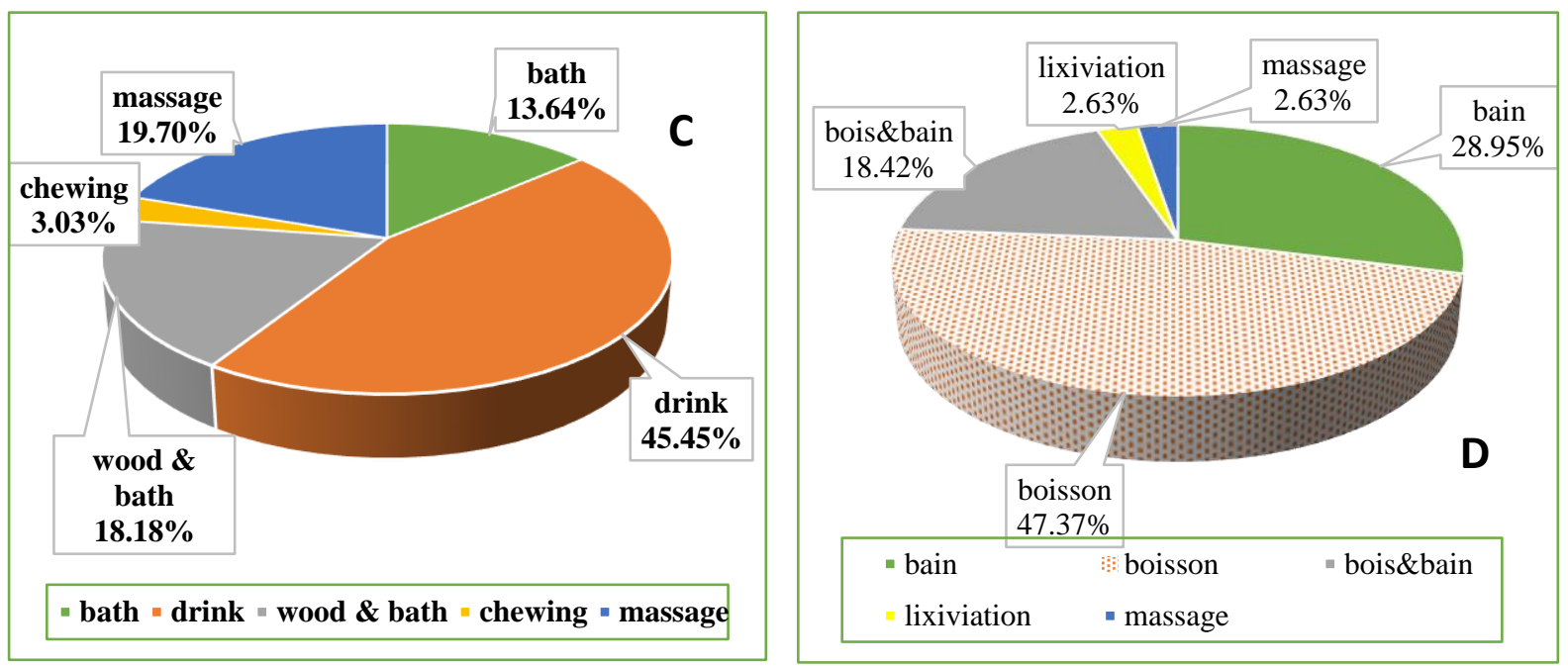

Figure 7 : Frequency of citation: A: of preparation mode ; B: of preparation mode C: administration mode ; D: administration mode

\section{Extraction yields}

Yields are expressed as a percentage of dry matter. The yields ranged from $6.69 \%$ to $26.34 \%$. The leaf extract of $F$. virosa gave a higher yield with $26.34 \%$ and the best yield in E. poissonii was obtained with the bark extract $(10.84 \%)$.

\section{Determination of polyphenolic compounds and antioxidant activities}

\section{Determination of polyphenolic compounds}

In this study, we evaluated the content of total phenolics and flavonoids in our total methanolic extracts. The folin-ciocalteu method was used for the quantification of total phenolics and the aluminum chloride method for total flavonoids. The results of total phenolic contents of methanolic extracts ranged from $22.06 \pm 1.4$ to $52.05 \pm 1.49 \mathrm{mg}$ EAG/100 mg. In F. virosa the best result was obtained in the leaves with $52.05 \pm 1.49 \mathrm{mg} \mathrm{EAG} / 100 \mathrm{mg}$. As for E. poissonii, the highest value was found in the bark $(24.06 \pm 2.16 \mathrm{mg} E A G / 100 \mathrm{mg})$. The results of the total flavonoid determinations of the methanolic extracts ranged from $0.73 \pm 0.12$ to $3.30 \pm$ $0.32 \mathrm{mg} \mathrm{EQ} / 100 \mathrm{mg}$. The bark gave the best result $(3.30 \pm 0.32 \mathrm{mg} \mathrm{QE} / 100 \mathrm{mg})$ for the different parts of F. virosa. As for E. poissonii the highest content was obtained with the leaves $(2.72 \pm 0.56 \mathrm{mg} \mathrm{EQ} / 100 \mathrm{mg})$ whose results are recorded in Table 1. 
Table 1: Results of the determination of polyphenolic compounds

\begin{tabular}{llcc}
\hline Plants & Parts used & $\begin{array}{c}\text { Total phenolics }(\mathrm{mg} \\
\text { (EAG)/100mg) }\end{array}$ & $\begin{array}{c}\text { Total flavonoids }(\mathrm{mg} \\
(\mathrm{EQ}) / 100 \mathrm{mg})\end{array}$ \\
\hline \multirow{3}{*}{ Flueggea virosa } & leaves & $52,06 \pm 1,49^{\mathrm{a}}$ & $2,01 \pm 0,61^{\mathrm{cd}}$ \\
& Roots & $39,13 \pm 1,60^{\mathrm{c}}$ & $1,95 \pm 0,84^{\mathrm{d}}$ \\
& barks & $42,13 \pm 6,06^{\mathrm{b}}$ & $3,30 \pm 0,32^{\mathrm{a}}$ \\
\hline Euphorbia poissonii & Leaves & $24,06 \pm 2,16^{\mathrm{d}}$ & $2,72 \pm 0,56^{\mathrm{b}}$ \\
& barks & $22,06 \pm 1,4^{\mathrm{e}}$ & $0,73 \pm 0,12^{\mathrm{e}}$
\end{tabular}

Values are mean $\pm S D(n=3)$. Different letters in the same column indicate significant difference $(p<0.05)$.

For polyphenolic compounds assays, Flueggea virosa leaves presented the highest total phenolic contents with $52.06 \pm 1.49 \mathrm{mg}$ EAG/100 mg. Also, high total flavonoid contents were obtained with Flueggea virosa barks $(3.30 \pm 0.32 \mathrm{mg}$ QE/100 mg). These results could lead us to say that the peripheral parts store more polyphenolic compounds than the other organs. This distribution varies from one plant to another and according to their roles. Their content can be modified by abiotic factors such as exposure, altitude, climate, season, age and by biotic factors such as man and animals. Other researchers in South Africa who worked on F.virosa, had found $156.43 \pm 1.23 \mathrm{mg} \mathrm{GAE} / \mathrm{g}$ as total phenolic content of acetone extracts of $F$. virosa roots (Chauke et al., 2012). Compared to our work which gave $391.30 \pm 1.60 \mathrm{mg}$ EAG/g as the total phenolic content, the results of Chauke et al. (2012) are lower than ours. This difference in our results could be justified by the type of solvent used. Indeed, the composition of secondary metabolites in the two types of extract is different because acetone is less polar than methanol. This result could also mean that the secondary metabolites in the F. virosa root extract would be mostly polar.

\section{Antioxidant activities}

Three techniques were used to test the antioxidant activity of our total methanolic extracts. These are the $\mathrm{ABTS}^{\bullet+}$, $\mathrm{DPPH}^{\bullet}$ and the FRAP method. The reducing power of the total methanolic extracts by FRAP assay, ranged from $144.69 \pm 10.03 \mu \mathrm{mol}$ EAA/g to $3235.81 \pm$ $55.82 \mu \mathrm{mol} \mathrm{EAA} / \mathrm{g}$ with the different extracts from the organs of both plants. For the DPPH ${ }^{\bullet}$ assay, the results obtained ranged from $218.73 \pm 6.43 \mu \mathrm{mol}$ EAA/g to $903.95 \pm 7.80 \mu \mathrm{mol}$ EAA/g. For the $\mathrm{ABTS}^{\bullet+}$ assay, extracts of both species gave contents ranging from $3028.96 \pm 260.02 \mu \mathrm{mol} \mathrm{EAA} / \mathrm{g}$ to $8533.97 \pm 208.18 \mu \mathrm{mol} \mathrm{EAA} / \mathrm{g}$ with the different parts. The overall results of the antioxidant activities are reported in Table 2. 
African Journal of Biology and Medical Research

ISSN: 2689-534X

Volume 5, Issue 1, 2022 (pp. 1-16)

www.abjournals.org

Table 2: Antioxidant activities of methanolic extracts

\begin{tabular}{lllll}
\hline Tests & & $\begin{array}{l}\mathrm{DPPH}^{\bullet}(\boldsymbol{\mu m o l} \\
(\mathbf{A A E}) / \mathbf{g})\end{array}$ & $\begin{array}{l}\text { FRAP }(\boldsymbol{\mu m o l} \\
(\mathbf{A A E}) / \mathbf{g})\end{array}$ & $\begin{array}{l}\mathrm{ABTS}^{\bullet+}(\boldsymbol{\mu m o l} \\
(\mathbf{A A E}) / \mathbf{g})\end{array}$ \\
\hline \multirow{3}{*}{ F. virosa } & Leaves & $753,22 \pm 66,26^{\mathrm{c}}$ & $3235,81 \pm 55,82^{\mathrm{a}}$ & $8077,22 \pm 99,23^{\mathrm{c}}$ \\
& Barks & $903,95 \pm 7,80^{\mathrm{a}}$ & $2020,21 \pm 140,35^{\mathrm{b}}$ & $8533,97 \pm 208,18^{\mathrm{a}}$ \\
& Roots & $809,38 \pm 17,67^{\mathrm{b}}$ & $1800,265 \pm 101,75^{\mathrm{c}}$ & $8413,78 \pm 110,16^{\mathrm{b}}$ \\
& Leaves & $218,73 \pm 6,43^{\mathrm{e}}$ & $144,69 \pm 10,03^{\mathrm{e}}$ & $3028,96 \quad \pm$ \\
& & & & $260,02 \mathrm{e}$ \\
& Barks & $621,31 \pm 33,90^{\mathrm{d}}$ & $1122,97 \pm 80,22^{\mathrm{d}}$ & $4615,55 \pm 249,82^{\mathrm{d}}$ \\
\hline
\end{tabular}

Values are mean $\pm S D(n=3)$. Different letters in the same column indicate significant difference $(p<0.05)$.

Both species presented interesting antioxidant activities with the different antioxidant tests namely the test by DPPH ${ }^{\bullet}$, ABTS ${ }^{\bullet+}$ and FRAP. In the FRAP method, $F$. virosa leaves showed high antioxidant activity content with a value of $3235.81 \pm 55.82 \mu \mathrm{mol} \mathrm{EAA} / \mathrm{g}$. As for the ABTS $\bullet+$ method, it is still the barks of F.virosa presented with a high content of $8533.97 \pm 208.18$ $\mu \mathrm{mol}$ EAA $/ \mathrm{g}$. This shows the importance of secondary metabolite distributions and their defensive roles for the plant. Secondary metabolites do not participate directly in the basic processes of the living cell as opposed to primary metabolites produced by the plant to defend itself, for their organoleptic qualities (color, astringency, aroma ...). This could justify the orientation towards its organs by traditional practitioners during their harvests. Other researchers have tested the anti-free radical activity of Flueggea virosa extracts by the DPPH method. The ethanolic extract of $F$. virosa was found to be more antioxidant with an IC50 of $0.72 \mathrm{~g} / \mathrm{l}$ (Agbodan et al., 2017). Furthermore, in their study Chauke et al. (2012) found that acetone extracts of Flueggea virosa had high antioxidant activity with an IC50 of $30 \mu \mathrm{g} / \mathrm{ml}$, closely matching the activity of ascorbic acid with an IC50 of $25 \mu \mathrm{g} / \mathrm{ml}$. The results of our antioxidant activities revealed that the methanolic extract of F.virosa was the one with higher total phenolic content (Table 1) and also the one with good antioxidant activity by DPPH method $(753.22 \pm 66.26 \mu \mathrm{mol} \mathrm{EAA} / \mathrm{g})$ and by ABTS method $(8533.97 \pm 208.18 \mu \mathrm{mol} \mathrm{EAA} / \mathrm{g})$ (Table 2). Also, Sanogo et al. (2009) in their study on F. virosa, had shown that kaempferol 3O-(4-galloyl)- $\beta$-D-glucopyranoside presented a better antioxidant activity being also able to modulate the creation of hydroxyl radicals in a more efficient way, acting as a direct scavenger of hydroxyl radicals and chelating the iron. As for E. poissonii, the best antioxidant activity was found also by DPPH $(218.73 \pm 6.43 \mu \mathrm{mol}$ EAA/g and ABTS $(4615.55 \pm 249.82 \mu \mathrm{mol}$ $\mathrm{EAA} / \mathrm{g})$.

\section{CONCLUSION}

The ethnobotanical survey involved 103 traditional practitioners and identified 47 species divided into 27 families used in the treatment of breast cancer. As a result of this ethnobotanical survey, Euporbia poissonii and Flueggea virosa were selected for their phytochemical and antioxidant activities leading to interesting results. Antioxidant activities are plant-dependent and $F$. virosa has the best activities especially with FRAP $(3235.81 \pm 55.82 \mu \mathrm{mol}(\mathrm{AAE}) / \mathrm{g})$ with leaves, $\left.\operatorname{ABTS}^{\bullet+}(8533.97 \pm 208.18 \mu \mathrm{mol}(\mathrm{AAE}) / \mathrm{g})\right)$ and $\mathrm{DPPH}^{\bullet}(903.95 \pm 7.80 \mu \mathrm{mol}$ 
(AAE)/g) with barks. We believe that the anti-cancer activities are related to the presence of these secondary metabolites in the organs of the medicinal plant. Thus, the presence of polyphenolic compounds and the antioxidant activity could justify in part the use of these plant species in the treatment of breast cancer. Our next study will attempt to identify the different recipes used; as well as to study the different toxicities followed by anti-cancer activities on the cell lines in order to realize bio-guidance techniques for the commercialization of improved traditional drugs.

\section{Acknowledgments}

The authors are grateful to the associations of practitioners of the cities of Bobo-Dioulasso and Fada N'Gourma whose practitioners agreed to share their know-how.

\section{REFERENCES}

Abou-chaar, C.I, Shamlian, S.N. (1980). A Chromatographic Study of the Anthraquinones of Rhamnus alaternus L. I. Extraction, Isolation and Identification of the Aglycones. Pharm. Biol., 18: 49-55.

Agbodan, K A, Simalou, O, Boyode P. (2017). Conditions of synergistic action of antiradical extracts of Flueggea virosa (Roxb. Ex Wild.) Royle and Crataeva adansonii Forst. f. with external acid-base inductions. Int. J. Biol. Chem. Sci., 11(3): 1124-1134.

ALIAM. (2017). Cancer in French-speaking Africa, www.aliam.org

Arbonnier, M. (2002). Arbres, arbustes et lianes des zones sèches d'Afrique de l'Ouest ",CIRAD, MNHN, UICN.

Ashidi, J S, Houghton, P J, Hlands, P J, Efferth T. (2010). Ethnobotanical survey and cytotoxicity testing of plants of South-Western Nigeria used to treat cancer, with isolation of cytotoxic constituents from Cajanus cajan Millsp. Leaves. Journal of Ethnopharmacology., $128: 501-512$.

Bangou, M J, Almaraz-Abarca, N, Méda, N T R, Zeba, B, Kiendrebéogo, M, MillogoRasolodimby, J, Nacoulma, O G. (2012). Polyphenolic composition of Lantana camara and Lippia chevalieri, and their antioxidant and antimicrobial activities. International Journal of Phytomedicine , $4: 115-124$.

Bayala, B, Bassole, I H N, Gnoula C. (2014). Chemical composition, antioxidant, antiinflammatory and anti-proliferative activities of essential oils of plants from Burkina Faso. PloS One., 9(3):e92122.

Belkhiri, F. (2018). Activité Antimicrobienne et Antioxydante de deux Plantes Médicinales:Salvia verbenaca et Lepidium stadium. Thèse de Doctorat. Université Ferhat Abbas Sétif, 170p

Chauke, A M, Shai, L J, Mphahlele, P M, Mogale, M A. (2012). Radial Scavenging Activity of selected Medicinal Plants from Limpopo Province of South Africa, Africa Journal of Traditional complement and Alternative Medicine., 9(3) : 426-430.

Coulidiati, T H, Sombié, P A E D, Bangou, M J, Kiendrébéogo, M. (2019). The burden of cancer and the role of traditional medicine in Burkina Faso. Int J Complément Alt Med., 12(5):194 201 
Dakio, B, Bangou, MJ, Ouoba, P, Ouoba, YH. (2020). Medicinal Plants used in the Treatment of Hepatitis in Bobo-Dioulasso: Studying the Availability and Analyzing the Phytochemical Properties of Combretum micranthum G. Don and Entada africana. Academic Journal of Life Sciences. Vol. 6, Issue. 8, pp: 101-107. https://doi.org/10.19044/esj.2020.v16n40p1

Gbesso, G H F, Logbo, J, Daho, J E C A. (2020). Variability between socio-cultural groups and generations of Traditional knowledge on the use of Euphorbia poissonii Pax in Benin. Asian Journal of Applied Sciences, Volume 8 - Numéro 3.

GLOBOCAN. (2012). Cancer incidence and mortality worldwide :IARC CancerBase.

Gnoula, C, Mégalizzi, V, de Nève, N, et al. (2008). Balanitin-6 and -7: diosgenyl saponins isolated from Balanites aegyptiaca Del. display significant anti- tumor activity in vitro and in vivo. Inter J Oncol. 2008;32:5-15.

GUINKO, S. (1984). Étude de la végétation de la Haute Volta. Thèse de doctorat d'Etat et Science Naturelles, Bordeaux III, 2 vol 394 p.

Kareru, P G, Kenji, G M, Gachanja, A N, Keriko, J M, Mungai, G. (2007). Traditional medicines among the embu and mbeere people of Kenya. Afr.J. Trad.CAM., 4(1):7586

Magaji, M G, Musa, A M, Abdullahi M I, Yau, J, I Hussaini, M. (2015). Isolation of bergenin from the root bark of Securinega virosa and evaluation of its potential sleep promoting effect, Avicenna journal of Phytomedicine, 5(6) : 587-596.

Ministry of Health. (2017). Strategic plan for cancer control.

Monographie de la Région de 1'Est. (2009). Recensement général de la population et de l'habitation de 2006.

Monkodkaew, S, Loetchutinat, C, Nuntasaen, N, Pompimon, W. (2009). Identification and Antiproliferative Activity Evaluation of a Series of Triterpenoids Isolated from Flueggea virosa (Roxb. ex Willd.). American Journal of Applied Sciences., 6 (10) : 1800-1806.

NACOULMA-OUÉDRAOGO, O.G. (1996). Plantes médicinales et pratiques médicales traditionnelles au Burkina Faso : cas du plateau central. Thèse de doctorat d'État, Faculté des sciences et techniques, Université de Ouagadougou, Burkina Faso, tome 1, 320 p., tome $2,285 \mathrm{p}$.

WHO. (2018). Latest global cancer data: cancer burden reaches 18.1 million new cases and 9.6 million cancer deaths in 2018, No. 263

Ouédraogo, H. (1992). Aspects épidémio-cliniques et anatomo-pathologiques du cancer du sein chez la femme au Burkina Faso. Etude rétrospective portant sur huit ans. Th. Méd., Ouagadougou n ${ }^{\circ} 3$

Ouoba, P, Ouédraogo, A, Traoré, S. (2018). Savoirs culinaires et identités socio-culturelles : cas de l'utilisation de Cissus populnea Guill.\& Perr., le gombo de l'ethnie bobo au Burkina faso. Tropicultura, 36, 4 , 595-607.

Sano, D, Cisse, D R, Dao, B, Lankoande, J, Traore, S S, Soudre, R B, Sanou, A. (1998). Le cancer du sein, Problemes diagnostiques et thérapeutiques au chu de ouagadougou. Médecine d'Afrique Noire, 45 (5)

Sanogo, R, Vassallo, A, Malafronte, N, Imparato, S, Russo, A, Piaz F D. (2009). New phenolic glycosides from Securinega vorosa and their antioxidant activity. Science Naturelles, Bordeaux III , 2 vol 394 p.

Tatematsu, H, Mori, M, Yang,T H, Chang, J J, Lee, T T, Lee K. (1991). Cytotoxic PrincipIes of Securinega virosa: Virosecurinine and Viroallosecurinine and Related Derivatives, Journal of Pharmaceutical Sciences, Vol. 80, No. 4 
Thiombiano, A, Schmidt, M, Dressler, S, Ouédraogo A, Hahn, K, Zizka G. (2012). Catalogue des plantes vasculaire du Burkina Faso. Boissiera / Conservatoire et Jardin Botaniques de la ville de Genève., Volume 65. 391 p.

Zakkad, F. (2017). Etude Phytochimique Et Evaluation De Quelques Propriétés Biologiques De Trois Espèces De L'euphorbia. Thèse de doctorat. UNIVERSITE BADJI MOKHTAR- ANNABA, 2017.

Zerbo, P, Millogo-Rasolodimby, J, Nacoulma-Ouedraogo, O G, Van Damme, P. (2011). Plantes médicinales et pratiques médicales au Burkina Faso : cas des Sanan. Bois et forêts des tropiques, $\mathrm{n}^{\circ} 307$ ( 1 )

Zongo, N, Millogo-Traore, T F D, Bagre, S C, Bagué, A H, Ouangre, E, Zida, M , Bambara, A, Bambara, T A, Traoré, S S. (2015). Place of surgery in the management of breast cancer in women at the Yalgado Ouedraogo University Hospital: about 81 cases. Pan African Medical Journal. , 22:117 https://doi:10.11604/pamj.2015.22.117.6929 